\title{
Capturing the meaning of "free range": the contest between producers, supermarkets and consumers for the higher welfare egg label in Australia
}

\author{
Rachel Carey ${ }^{1}$ \\ Christine Parker ${ }^{2}$ \\ Gyorgy Scrinis ${ }^{1}$
}

Journal of Rural Studies, 2017, 54, 266-275

${ }^{1}$ Faculty of Veterinary and Agricultural Sciences, The University of Melbourne, Parkville, Victoria 3010, Australia

${ }^{2}$ Melbourne Law School, The University of Melbourne, 185 Pelham St, Carlton, Victoria 3053, Australia

\begin{abstract}
This paper shows how the Australian egg industry maintained its preferred definition of "free range" eggs in the face of a powerful consumer-oriented challenge to its labelling practices. We show how a consumer law initiative intended to enhance consumer confidence and address misleading labelling of industrial-scale egg production as "free range", was reframed through the policy consultation process, so that the primary policy problem became one of assuring industry certainty in a volatile contest for control over the governance of "free range" labelling. Drawing on notions of contests for power in regulatory space, we show how a policy coalition of egg industry and government primary industries actors successfully advocated for "free range" to be legally defined in a new consumer law information standard in accordance with existing, industrial-scale free range production systems, rather than the smaller scale systems preferred by consumer and animal welfare advocates. While this decision reflects the traditional regulatory capture by agricultural industries of Australian food and animal welfare policy decision making, we suggest that it equally reflects the existing power structure in the retail egg market - namely the two major supermarkets' adoption of industrial free range as their own standard for higher welfare egg labelling.
\end{abstract}

Keywords: Food labelling; egg industry; free range; regulatory capture; Australia; food policy 


\section{Introduction}

At the beginning of 2015, Australian federal and state consumer affairs ministers ${ }^{1}$ together announced the introduction of a mandatory new information standard for "free range" eggs. This long awaited regulatory clarification of the meaning of free range was originally intended to "enhance consumer confidence and certainty around egg labelling" and to "respond to growing consumer demand in the face of confusing and potentially false and misleading claims in the market" (CAF, 2015, p. 2). By the time the new standard was announced in March 2016, however, the objective had changed to incorporate both "giv[ing] more information to consumers" but also importantly, "reduc[ing] the regulatory uncertainty faced by egg producers and encourage[ing] investment in the industry" (CAF, 2016). To the disappointment of both consumer and animal welfare advocates, the new "free range" information standard enshrined a maximum outdoor stocking density of 10,000 hens per hectare (in comparison with the 1,500 to 2,500 hens per hectare that they had advocated) and provided only for "meaningful and regular access to the outdoors", without specifying further conditions such as size and positioning of doors to the outside, conditions on the range, and opportunities for natural behaviours such as dust bathing, pecking and scratching (Bettles, 2016a; Choice, 2016).

This paper shows how the egg industry was able to shape the consumer law initiative, with the support of primary industries ministers, to define the meaning of "free range" eggs in accordance with existing, industrial-scale, barn-based free range production systems, rather than the smaller scale, outdoors-based systems preferred by consumer advocates and some other stakeholders.

Drawing on the concept of "regulatory space" (Hancher and Moran, 1998), we analyse how industry actors were able to "capture" the development of the consumer information standard (Goodfellow, 2016), even in an age of consumer challenge to primary industry power (Dixon, 2003; Roff, 2007), and with increasing public support for higher animal welfare standards (Chen, 2016).

Much food systems literature points out the significance of industry and corporate influence over food system governance (Lang and Heasman, 2015; Stuckler and Nestle, 2012; Clapp, 2012). In Australia, the captured relationship between primary industries and Australian government has been particularly infuential. Yet we suggest that the egg industry's traditional "cozy" (Marangos, 2009) relationship with government and primary industries departments, while an important part of the story, is not the whole story. As Lang and Heasman (2015) point out, the retailers are the power brokers between consumers and industry in the contemporary food system. We suggest that it was the tacit alignment of the new free range standard with supermarket requirements that ultimately allowed the egg industry to maintain its preferred view of "free range" as industrialscale free range.

The first section of this article outlines the background and policy context for the highly contested debate about "free range" eggs in Australia, showing how consumer demand and

\footnotetext{
${ }^{1}$ Australia is a federation of states and territories, and both federal (national) and state governments have responsibilities for policy across many portfolios, including agriculture and consumer law. Australian Consumer Law is administered jointly by the Australian Competition and Consumer Commission (ACCC) and state and territory consumer affairs agencies.
} 
advocacy by civil society groups led to the opening of a "policy window" (Kingdon, 2011) or opportunity for change. The second section reviews the history of regulatory capture of animal welfare standard setting by primary industries in Australia in the context of literature on corporate influence over food system governance. We argue that the development of food labelling policy is a contested "regulatory space" in the contemporary retail dominated food system, and we outline our policy analytic framework for evaluating the influence of industry, government and civil society in the unfolding debate over the mandatory free range information standard. The third section goes on to describe the data and methodology used for this study.

The fourth section presents our findings. We show how a consumer advocacy group, Choice, opened the initial "policy window", creating the opportunity for the free range standard. Yet, when a second policy window was opened through a consultation on the standard, the egg industry was able to establish an advocacy coalition (Sabatier and Jenkins-Smith, 1999) with primary industries ministers that successfully reframed the policy problem (Weiss, 1989) as one of industry (not consumer) uncertainty. Crucially, the proposal put forward by the egg industry coalition mirrored the requirements of the major Australian retailers. Thus the labelling reform process shifted from one originally intended to halt misleading "industrial" free range claims on egg cartons (The Treasury, 2015) to one that enshrined "industrial" free range as the regulatory standard for free range eggs. The final section discusses the implications of these findings and the possibility of further contestation and change in the future 


\section{Background}

\subsection{Contestation of "free range" egg labelling}

Production systems labelled "free range" emerged in Australia in the 1980s in response to increasing consumer concern about animals being held in confinement (Parker et al., 2016; see also Miele 2011). In some countries, notably the European Union (EU Council, 1999; see also NAWC, 2012; Mench et al., 2011), animal welfare concerns led to a ban on conventional cages. In Australia, by contrast, governments responded to industry lobbying and rejected a ban on conventional cages in 2000. Instead they left it to industry to label eggs as cage, barn or free range in order to enable informed consumer choice over animal welfare values (SCARM, 2000; Parker and De Costa, 2016). Animal welfare NGOs responded by urging consumers to buy cagefree and Australia's two dominant supermarkets both promoted higher animal welfare own brand products (especially free range eggs) in a bid to secure customer loyalty (Parker and Scrinis, 2014; Lewis and Huber, 2015). The result was a rapid growth in the proportion of eggs sold as "free range", with $40 \%$ of retail eggs sold in Australia now free range (Tonkin, 2014). However, the meaning of this term has been strongly contested.

Animal advocates and many consumers see "free range" as a smaller scale, higher animal welfare choice, with hens housed in small, often mobile sheds, and provided open access to wellpastured fields and many opportunities for natural behaviours such as pecking, dust bathing and perching (Choice, 2012). We refer to this as "small-scale free range". The business model that has emerged to satisfy consumers' and large supermarket's demand for higher welfare labelled eggs has, however, depended on hens housed in large scale intensive sheds $(10,000$ or more chickens per shed) with access to the outdoors via flaps or popholes (Parker and De Costa, 2016). We refer to this model as "industrial-scale free range".

By 2011, Members of Parliament from the Australian Greens party ${ }^{2}$, consumer advocates, animal activists and some smaller scale egg producers were all advocating for mandatory labelling laws in Australia to define free range (e.g. Smith, 2011; see Parker et al., 2016; Chen, 2016). Such laws had been passed in the UK (FAWC, 2006) and EU (Commission of the European Communities, 2009). However, the Australian government refused to legislate for free range, seeing it as a "consumer values" issues, not appropriate for mandatory regulation (Blewett et al. 2011). This moved contestation of the meaning of free range to the consumer protection law arena, where the Australian Competition and Consumer Commission (ACCC), Australia's federal consumer protection regulator, has played a significant role, focusing particularly on the maximum outdoor stocking density that should be allowed for free range hens, and whether or not hens should have "access to" an outdoor range or should actually go outdoors on most ordinary days (ACCC, 2015).

In 2012, the ACCC rejected an application by the egg industry body, the Australian Egg Corporation Ltd (AECL), for an industry quality assurance trademark that included a definition of free range eggs based on a stocking density of up to 20,000 hens per hectare (ACCC, 2012). This represented current practice at that time. The stocking density debate has since evolved into

\footnotetext{
${ }^{2}$ The Australian Greens is a political party with its roots in the environment movement.
} 
a debate about whether eggs labeled free range should have a maximum outdoor stocking density of 1,500 to 2,500 hens per hectare, as smaller scale free egg range producers argue; or up to 10,000 birds per hectare, the compromise standard now enforced by Australia's two major retailers (Fyfe and Millar, 2013; Woolworths, 2013). Moreover after 2012, the ACCC successfully brought cases against a number of free range egg producers for misleading and deceptive conduct on the basis that hens were not able to "move about freely on an open range each day" (ACCC, 2013, p. 1).

This set the stage for consumer advocacy group, Choice, to bring a "super complaint" to consumer protection authorities in 2013, claiming that free range egg claims had "considerable potential to mislead consumers" (Choice, 2013). This super complaint ultimately initiated the process of development of a mandatory free range labelling standard by consumer affairs ministers, and the contest between the egg industry and consumer and animal welfare advocates which is the subject of this study.

\subsection{Australian agri-food context}

The Australian agrifood context is one in which agricultural industries have significant political power based on their historical importance to the Australian economy, and a tradition of "closed policy networks", centred on state-based marketing bodies (Chen, 2016). The egg industry itself is dominated by three large domestic egg suppliers (Pace, Sunny Queen, and Farm Pride), who together control about $60 \%$ of the market (Tonkin, 2014). These corporations emerged in the 1990s and early 2000s out of state-based egg marketing boards as a result of the process of competition policy reform (Industry Commission, 1991; Marangos, 2009).

While the economic importance of the agricultural industries has now waned, and statesanctioned market protection mechanisms have been dismantled, agri-political organisations in Australia remain powerful (Chen, 2016). Lobbying by the egg industry was highly influential in the 2000 decision not to ban conventional cages for battery hens in Australia (SCARM, 2000). Lobbying by the agricultural industries has also influenced the trajectory of a number of other significant food policy developments in Australia, such as the National Food Plan (Carey et al., 2016; Ridgway, Lawrence and Woods, 2015) and the decision not to base the 2013 Australian Dietary Guidelines on advice about how to eat sustainably as well as healthily (Jelsoe, 2015).

The political power of the agriculture sector is strengthened by the influence on Australian politics of the National Party, a political party that has its roots in farming. The National Party (then the Country Party) was formed by farmers in the early 20th Century (Gray and Lawrence, 2004), and is still strong in rural electorates (Curtin, 2000). Although formal ties to farmer interest groups have long since been dissolved, primary industries and the lobbying of agripolitical organisations still find a naturally sympathetic ear with National Party representatives, and the claims of the country on the city are still culturally resonant in Australian politics (Brett, 2011). Members of the National Party can occupy powerful government ministries, including Deputy Prime Minister and Trade Minister (Marangos, 2009). A charismatic National Party MP, Barnaby Joyce, currently holds the positions of Minister of Agriculture and Deputy Prime Minister in Australia's Liberal National coalition government. With a policy focus on growing agricultural exports to Asia (Commonwealth of Australia, 2015), the primary industry lobby is still able to exert significant influence to protect farming industry interests at the highest levels of Australian policy making. 
In recent years, however, Australia's two dominant retailers, Coles and Woolworths, have grown in market power at the expense of agricultural industries. Together the two supermarkets hold around 60 percent of the grocery market (ACCC, 2008). They use their market power to dictate the terms of trade to both suppliers and consumers, and Australia's Competition and Consumer Commission (ACCC) has taken action against the retailers on a number of occasions for misleading and deceptive conduct and misuse of market power with varying success (Parker and Scrinis, 2014). These retailers have also used their considerable market power to shape the meaning of "free range" by announcing that they would stock only cage free eggs and by developing their own private standards for free range (Parker and Scrinis, 2014; see also Fuchs, Kalfagianni and Arentsen, 2009).

\section{Theory}

\subsection{Corporate power in food system governance}

The highly concentrated nature of both Australia's egg industry and supermarket sector is consistent with the more general observation of corporate concentration of power across all sectors of the food system in recent decades (Lang and Heasman, 2015; Stuckler and Nestle 2012; Clapp 2012). Increased market power has led to increased influence over the regulatory structures and institutions that govern the rules by which agrifood corporations operate (Clapp and Fuchs, 2009). Evidence has emerged of corporate influence over nutrition policy and regulation (Nestle, 2013; Clapp and Scrinis, 2017; Mialon et al 2016) and the sustainability of the global food system (Fuchs, Kalfagianni and Arentsen, 2009; Jaffee and Howard 2010; Richards et al, 2015). The strategies used by corporations to influence food system governance include direct lobbying of policy makers, shaping policy discourse in the public debate and active participation in rule-making and standard-setting (Clapp and Fuchs 2009; Clapp and Scrinis 2017; Smythe 2009).

\subsection{Regulatory "capture" and regulatory space}

The concept of "regulatory capture" has been used to explain how corporations exert influence to undermine regulation in the public interest (Stigler, 1971; Dal Bo, 2006; Carpenter and Moss, 2014). According to the theory of regulatory capture, regulation that should operate in the public interest is "acquired" by corporate interests, as a result of their power and influence, so that it operates primarily for their benefit (Dal Bo, 2006). Researchers have identified some of the mechanisms of corporate capture, such as the "revolving door" between government and industry employment (Dal Bo, 2006), the "dual mandates" of some government departments for both industry and public interests (Goodfellow, 2016) and "cultural capture", in which regulators adopt industry beliefs and values (Kwak, 2014). Studies of "regulatory capture" have come under criticism for presenting insufficient empirical evidence to support their claims and for failing to account for how regulatory capture operates in practice within specific settings (Dal Bo, 2006; Carpenter and Moss, 2014). But in Australia Goodfellow (2016, p. 229) has shown through careful empirical analysis that Australian Departments of Primary Industries (state government departments of agriculture) have "deviated from serving the public interest in farm animal welfare" as a result of regulatory capture by the livestock industries. He argues that this capture has occurred largely through the dual mandates of these government departments for both animal welfare and agricultural productivity (see also Productivity Commission, 2016). 
Hancher and Moran (1998) argue that the concept of "regulatory capture" does not adequately account for the mechanisms of corporate influence on regulation, because in practice there is no clear division between public and private spheres of interest and activity. Rather than acting as "takers" of regulation made exclusively by public institutions, corporations themselves have acquired the status of "governing institutions", and regulation is shaped by complex interactions between public and private institutions (including negotiation and co-operation) in a shared "regulatory space" (Hancher and Moran, 1998). The task then, in understanding how corporate influence on regulation occurs in specific settings, is to identify which organisations occupy the "regulatory space" (and which are excluded) and the power relations between them (Scott, 2001; Burkard et al., 2014).

Drawing on this more nuanced understanding of "capture" as just one power mechanism within "regulatory space", this article shows how primary industry corporations and the associations that represent them exercised their power to maintain a definition of free range as industrial-scale free range, through an advocacy coalition with Departments of Primary Industries, and with the tacit acceptance of Australia's two powerful supermarkets. This regulatory space approach moves beyond a dichotomous view in which an industry captures or does not capture a particular regulatory agency and helps us understand the way in which networks and coalitions of actors are formed and create shifting alliances of power.

\subsection{Significance of Labels as a Regulatory Space}

The regulation of food labelling is a particularly important space for contests over the governance of the contemporary food system (Parker, 2014). On the one hand, with the rise of competition policy, it is assumed that food labels will inform consumers, who are then empowered to make choices based on their values (Guthmann, 2007; Klintman and Bostrom, 2004), overcoming the "distance" between consumers and the food system (Tonkin, 2014). On the other hand, food labels are also used for branding, including via ethical claims (such as higher welfare claims) to achieve market share. The development of new food labelling standards has thus become a site of significant stakeholder contestation as producers, retailers and civil society groups all seek to influence what is on the label. As the interface between producers and consumers, retailers in particular are emerging as powerful "food authorities", with great power to influence food labelling for their own benefit (Parker and Scrinis, 2014). This makes the contest over free range labelling standards in Australia a particularly fruitful site for analysis.

\subsection{Research question and analytic framework}

In order to illuminate the power relationships and mechanisms in regulatory space in relation to the battle over the mandatory information standard for free range egg labelling in Australia, we draw on three key concepts from policy analysis literature. First we highlight the framing of the policy problem as the heart of the policy process (Weiss, 1989). As Weiss suggests, "much policymaking... is preoccupied with whose definitions shall prevail" (Weiss, 1989, p. 98). Thus we analyze the shift in problem definition that took place during the policy development process and how this shaped the proposed policy solutions. Second, we do this by reference to two "policy windows" (Kingdon, 2011) that created the opportunity for two key shifts in the policy context for the national information standard - first towards consumer concerns and then back towards industry concerns. As Kingdon (2011) notes, once advocates open a policy window, it may set in motion a chain of events that becomes difficult to control and leads to unpredictable 
policy outcomes. This was certainly true in this case. Finally we draw on Sabatier's concept of advocacy coalitions to explore the role of two policy coalitions that each sought to influence the outcome of the national information standard in different directions (Sabatier and Jenkins-Smith, 1999). Sabatier proposes that actors in a policy subdomain are typically organized into advocacy coalitions that adopt common advocacy strategies, based on shared core beliefs about a policy problem and common policy objectives (Sabatier and Jenkins-Smith, 1999).

Our analysis of actors and advocacy coalitions in the policy domain also draws on Lang and Heasman's (2015) approach of categorizing food policy actors into three main sectors: government, industry (the private sector) and civil society, with subsectors within each (see Table 1).

\section{Research methods}

\subsection{Data collection}

Data were collected from a range of policy documents related to the national information standard for free range egg labelling. Documents were collected from 2012 (when the ACCC rejected an application from the national egg industry body for certification for free range labelling), to March 2016, when federal and state consumer affairs ministers (the Consumer Affairs Forum) announced their preferred approach to the development of the national information standard. The documents included media statements and policy announcements by key stakeholders - such as the egg industry, retailers, civil society groups and relevant government departments - as well as documents related to the Regulation Impact Statement (RIS) process for the development of the standard.

Australian Consumer Law is a joint national and state responsibility under Australia's federal system of government. RISs are developed for all Australian federal government policy proposals that involve new regulation and are part of the Australian Government's agenda to "cut red tape" and reduce new regulation (DPMC, 2014). An RIS defines the policy problem that is being addressed and presents a range of policy options with their benefits, risks and costs. Two RISs were released during the development of the national information standard for free range egg labelling. A Consultation RIS (The Treasury, 2015) was released to support a public consultation about the development of the standard, and a second Decision RIS (The Treasury, 2016) was later developed as a basis for consumer affairs ministers to decide on the development of the standard.

A stakeholder consultation took place during October and November 2015, based on the Consultation RIS. 149 submissions were made to the consultation, 114 of which were made public ( 35 were confidential). We analysed 47 of these public submissions from stakeholder organisations, excluding from our analysis submissions from individual members of the public. Analysis of formal submissions can only reveal so much, however, about stakeholder influence on policy processes, as behind the scenes meetings and lobbying also play a role. All the documents collected were publicly available. Submissions to the consultation process were downloaded from the website of the Australian Treasury, the federal government agency that led the development of the standard. Other documents associated with the RIS process were also 
downloaded from this website. Media releases and policy statements were downloaded from the websites of key stakeholders.

\subsection{Analysis}

The policy documents and submissions to the RIS process were analysed to identify (i) the way that stakeholder organisations defined the policy problem at each stage of the policy process (Weiss, 1989) and (ii) the proposed policy solutions (see section 5 for an overview of the key stages of the policy process). The data were coded using a process of thematic analysis (Guest, McQueen and Namey, 2012) in which key themes in the definition of the policy problem were identified and compared (a) across the four main stages of the policy process to track when shifts in problem definition occurred and (b) across key stakeholders to establish who had influenced the policy shifts. In identifying who had influenced policy shifts, particular attention was paid to comparing definitions of the policy problem in the RIS documents released by the Treasury (the government agency leading the development of the standard) with problem definitions in the submissions and policy statements of other key stakeholders.

Comparative analysis of patterns in proposed problem definitions and solutions across key stakeholders assisted in identifying "advocacy coalitions" of stakeholders who shared common policy objectives and beliefs (Sabatier and Jenkins-Smith, 1999). Submissions to the Consultation RIS sometimes expressed explicit support for submissions from other stakeholders, and this also assisted in identifying advocacy coalitions. Establishing who had influenced policy shifts and when the shifts occurred was also important in identifying the two "policy windows" (Kingdon, 2011) that created the opportunity for these shifts to occur.

\subsection{Key actors}

The submissions analysed included 10 submissions from government organisations, 22 from industry organisations and 15 from civil society organisations. Table 1 summarises the key actors identified in each category.

\begin{tabular}{|c|c|l|}
\hline Key actors & Sector & Role in the development of the National Information Standard \\
\hline Government & \multicolumn{3}{|c|}{$\begin{array}{c}\text { Consumer } \\
\text { regulator }\end{array}$} & $\begin{array}{l}\text { Australian Competition and Consumer Commission, the federal } \\
\text { government competition and consumer authority that took action against } \\
\text { some free range egg producers for misleading and deceptive conduct }\end{array}$ \\
\hline $\begin{array}{c}\text { Federal Court of } \\
\text { Australia }\end{array}$ & $\begin{array}{c}\text { Federal } \\
\text { government }\end{array}$ & Decides matters bought by the ACCC under Australian Consumer Law \\
\hline $\begin{array}{c}\text { Minister for } \\
\text { Agriculture } \\
\text { government }\end{array}$ & $\begin{array}{l}\text { Federal } \\
\text { The federal Minister for Agriculture, Barnaby Joyce, who is also deputy } \\
\text { prime Treasury } \\
\text { government }\end{array}$ & $\begin{array}{l}\text { Federal government department that acts as a central policy agency. It led } \\
\text { the development of the national information standard on behalf of } \\
\text { Consumer Affairs Australia and New Zealand (CAANZ) }\end{array}$ \\
\hline $\begin{array}{c}\text { NSW Fair Trading } \\
\text { Consumer } \\
\text { regulator }\end{array}$ & $\begin{array}{l}\text { Consumer affairs regulator for the state of New South Wales that } \\
\text { recommended the development of the National Information Standard }\end{array}$ \\
\hline $\begin{array}{c}\text { NSW Department } \\
\text { of Primary } \\
\text { Industries }\end{array}$ & $\begin{array}{c}\text { State } \\
\text { government }\end{array}$ & $\begin{array}{l}\text { The NSW agriculture department that supported the "free range" definition } \\
\text { proposed by Egg Farmers of Australia. Equivalent departments exist in all } \\
\text { states and territories of Australia }\end{array}$ \\
\hline $\begin{array}{c}\text { Australian Greens } \\
\text { Members of } \\
\text { Parliament }\end{array}$ & $\begin{array}{l}\text { Elected MPs from state branches of the Australian Greens, a national } \\
\text { political party with a focus on environmental politics. The Australian } \\
\text { Greens campaigned for a national information standard }\end{array}$ \\
\hline
\end{tabular}




\begin{tabular}{|c|c|c|}
\hline The Nationals & $\begin{array}{l}\text { Members of } \\
\text { Parliament }\end{array}$ & $\begin{array}{l}\text { Elected MPs from state branches of the National Party, a political party } \\
\text { that has traditionally represented farmers, graziers and people in regional } \\
\text { Australia }\end{array}$ \\
\hline \multicolumn{3}{|r|}{ (2) } \\
\hline $\begin{array}{l}\text { Egg Farmers of } \\
\text { Australia }\end{array}$ & Industry body & $\begin{array}{l}\text { National umbrella group, representing numerous state-based organizations } \\
\text { of egg farmers, that describes itself as "the voice of the Australian egg } \\
\text { industry". This group represented the views of industrial-scale egg farmers } \\
\text { (who supply to the major supermarkets) in the development of the } \\
\text { standard }\end{array}$ \\
\hline $\begin{array}{l}\text { Commercial Egg } \\
\text { Producers of WA, } \\
\text { Queensland } \\
\text { United Egg } \\
\text { Producers }\end{array}$ & Industry body & $\begin{array}{l}\text { State-based peak bodies representing industrial-scale egg producers. } \\
\text { These groups are affiliated with Egg Farmers of Australia }\end{array}$ \\
\hline $\begin{array}{l}\text { Industrial-scale } \\
\text { egg producers }\end{array}$ & Producers & $\begin{array}{l}\text { Industrial-scale egg producers that supply through the major retailers. } \\
\text { There are three dominant industiral-scale producers in Australia }\end{array}$ \\
\hline $\begin{array}{l}\text { Small-scale egg } \\
\text { producers }\end{array}$ & Producers & $\begin{array}{l}\text { Numerous free range egg producers who produce at small-scale, typically } \\
\text { using mobile pasture-based production systems }\end{array}$ \\
\hline $\begin{array}{l}\text { Coles and } \\
\text { Woolworths }\end{array}$ & Retailers & $\begin{array}{l}\text { Australia's two dominant national supermarket chains, which have both } \\
\text { committed to cage-free own brand eggs }\end{array}$ \\
\hline \multicolumn{3}{|l|}{ Civil society } \\
\hline CHOICE & $\begin{array}{c}\text { Consumer } \\
\text { advocacy group }\end{array}$ & $\begin{array}{l}\text { National consumer advocacy group that campaigned for a national } \\
\text { information standard for free range egg labelling }\end{array}$ \\
\hline $\begin{array}{l}\text { RSPCA, Animals } \\
\text { Australia, } \\
\text { Voiceless, } \\
\text { Humane Society } \\
\text { International }\end{array}$ & $\begin{array}{l}\text { Animal } \\
\text { advocacy } \\
\text { groups }\end{array}$ & $\begin{array}{l}\text { National animal welfare groups that campaigned to ban cages for laying } \\
\text { hens and advocated for a national information standard for free range egg } \\
\text { labelling }\end{array}$ \\
\hline
\end{tabular}

Table 1: Key actors in the development of the National Information Standard for free range eggs

\section{Results}

A significant shift took place in the definition of the policy problem in defining free range eggs from a problem of "consumer uncertainty" to a problem of "industry uncertainty" - through four key stages in the policy development process, described in each of the four subsections below. The announcement that a national information standard was to be prepared in response to Choice's super-complaint opened a policy window (section 5.1); and the release of the Consultation RIS defined the problem as one of consumer uncertainty in line with Choice's super-complaint and emerging ACCC case law (section 5.2). The public consultation opened a second policy window (section 5.3) which the egg industry used to contest the framing of the problem as consumer uncertainty with the problem of industry uncertainty; and finally the policy options presented to ministers in the decision RIS showed that the definition of the policy problem had undergone a fundamental shift from consumer uncertainty to industry uncertainty.

\subsection{The announcement - a window of opportunity is opened}

After many years of stakeholder advocacy and consumer pressure for mandatory labelling laws (see Figure 1 and section 2.1 in Background above), the development of a new national information standard for free range eggs was finally triggered by a "super complaint" in 2013

\footnotetext{
${ }^{3}$ Super complaints are intended to allow consumer advocacy organisations to bring forth concerns that affect a wide range of consumers for prioritised action.
} 
by the consumer advocacy organisation Choice. Choice presented evidence to NSW Fair Trading (the consumer affairs agency for the state of New South Wales) that the lack of an enforceable standard for free range eggs "means that many products labelled free-range are produced under conditions that are substantially inconsistent with voluntary standards and consumer expectations" "(Choice, 2013 p. 2), and it emphasized that consumers suffer because they pay a premium, "assuming that free-range products meet their ethical expectations" (Choice, $2013 \mathrm{p}$. 4).

NSW Fair Trading (2013) responded to the "super complaint" by recommending to federal and state consumer affairs ministers (the Consumer Affairs Forum) that a national information standard for free range egg labelling should be developed under Australian Consumer Law.

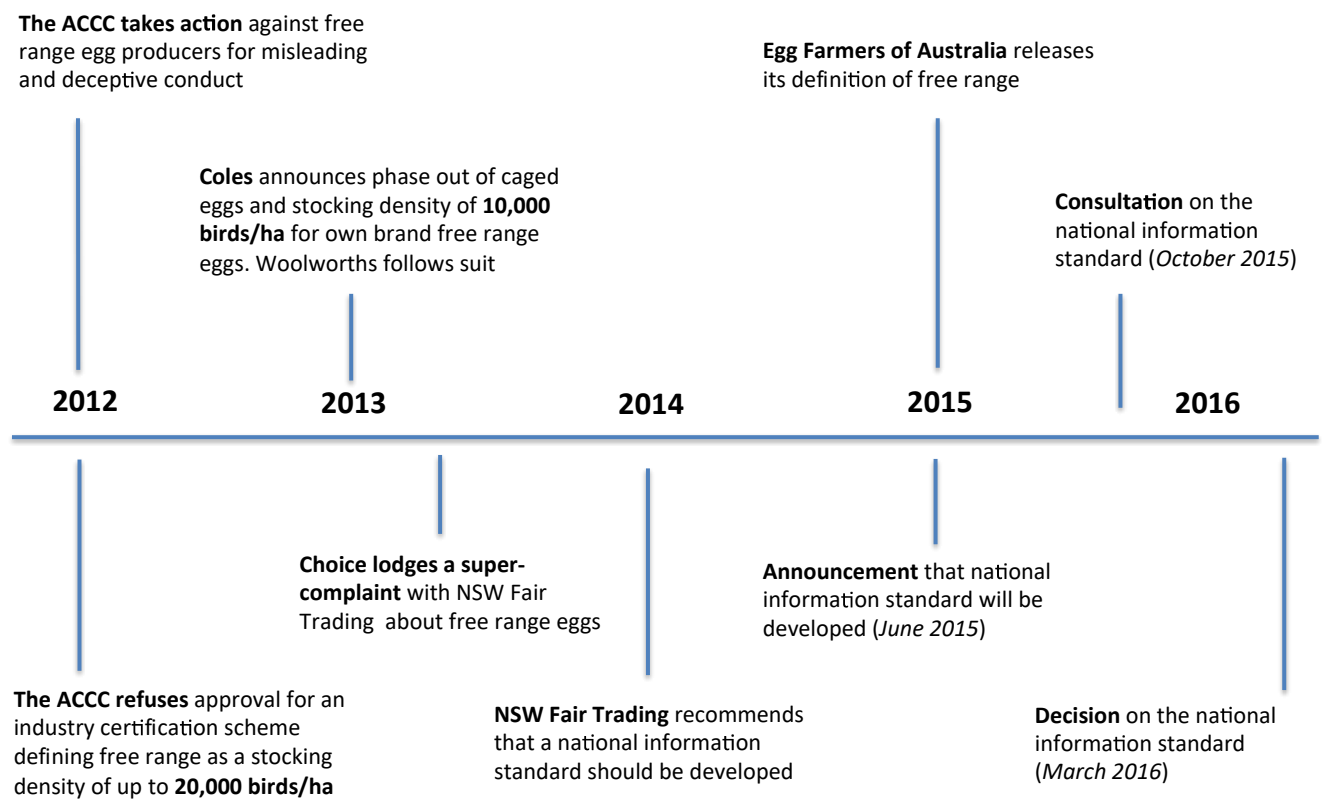

Figure 1: Timeline of events for the development of the national information standard for free range eggs

The announcement by consumer affairs' ministers in June 2015 presented the policy problem as one of consumer uncertainty. The Chair of the Consumer Affairs Forum commented that consumers expected "a free range hen needs to be able to range freely", and that he hoped the new standard would put an end to "the lack of certainty around terms that appear not to reflect what consumers understand those terms to mean" (Sampson, 2015). With its "super complaint", Choice had opened a window of opportunity for significant policy and legislative change. However, as Kingdon (2011) highlights, policy outcomes can be unpredictable, and in opening the "policy window", Choice set in motion a chain of events that would ultimately produce a result not to their liking.

\footnotetext{
${ }^{4}$ In making its arguments about consumer expectations, Choice drew on surveys of consumer perceptions about free range that it commissioned (Choice, 2012).
} 


\subsection{The consultation RIS - a problem of consumer uncertainty}

The "consumer uncertainty" definition of the policy problem continued in the Consultation RIS released for public comment in October 2015. The problem was described in the RIS as one of consumer "uncertainty" and "suffering", because eggs marketed as free range did not always meet consumer expectations of production practices (The Treasury, 2015, p. 9).

\begin{tabular}{|l|l|l|}
\hline Option 1 & Status Quo & $\begin{array}{l}\text { ACCC guidance and case law would establish appropriate } \\
\text { use of the term free range }\end{array}$ \\
\hline Option 2 & $\begin{array}{l}\text { Basic Information Standard for } \\
\text { Free Range Egg Labelling }\end{array}$ & $\begin{array}{l}\text { A basic information standard under Australian Consumer } \\
\text { Law would define requirements for labelling eggs as free } \\
\text { range }\end{array}$ \\
\hline Option 3 & $\begin{array}{l}\text { Information Standard For All } \\
\text { Categories of Eggs }\end{array}$ & $\begin{array}{l}\text { An information standard would require all eggs to be } \\
\text { labeled and would define requirements for labelling eggs } \\
\text { as "cage", "barn" or "free range" }\end{array}$ \\
\hline
\end{tabular}

Table 2: Options for the national information standard for free range eggs in the consultation RIS

The Consultation RIS presented three main policy options (summarized in Table 2). Each of the three policy options was based on a continuation of existing ACCC enforcement of consumer protection law and on a definition of "free range" where eggs are, "produced by hens that can, and do, move about freely on an open range on most ordinary days" (The Treasury, 2015, p. 19). However, this conflicted with the definition of free range preferred by Egg Farmers of Australia (EFA), a peak body representing the interests of Australian egg farmers, in which laying hens would "have access to" an outdoor range area and would be "free to roam and forage", but would not necessarily need to actually use the outdoor area (Egg Farmers of Australia, 2015).

\subsection{The consultation on the RIS - "Consumer uncertainty" versus "industry uncertainty"}

During the public consultation, the egg industry, led by EFA, promoted this alternate definition of free range. They also attempted to reframe the policy problem. EFA argued in its submission to the consultation that the problem that should be addressed through regulation was, "the approach adopted in judicial decisions and...regulator actions", which had created industry uncertainty (Egg Farmers of Australia, 2015, p. 25). In other words, the EFA attempted to shift the policy problem from one of consumer uncertainty, caused by misleading and deceptive marketing of free range eggs by egg producers, to a problem of industry uncertainty, caused by the actions of the ACCC and the Australian federal court in pursuing cases of misleading and deceptive conduct.

EFA was supported in its attempt to shift the policy problem by state-based organisations representing egg farmers (e.g. NSW Farmers, 2015; Commercial Egg Producers of WA, 2015; South Australian Local Egg Industry Section, 2015), submissions by some members of the Nationals Party (Williams, 2015; Burke, 2015) and by the NSW Department of Primary Industries (2015, p. 2), which argued that the definition of free range in the Consultation RIS "compounds the existing uncertainty created by the common law definition of free range egg production established in recent Federal Court findings", because egg producers were unable to guarantee that most hens would access the range on most ordinary days. These organisations 
formed an "advocacy coalition" (Sabatier and Jenkins-Smith, 1999), focused on the interests of industrial-scale egg producers. The involvement of a state department of agriculture and some members of the National Party in this "egg industry coalition" was indicative of the continuing close relationship between industry and government in primary industries policy making in Australia (Chen, 2016; Marangos, 2009).

This egg industry coalition argued that the ACCC had "over-reached" its remit, with the peak body for farmers in the state of New South Wales commenting, "the actions of the regulator have not been aimed at misleading and deceptive conduct and instead appear to be geared toward redefining an industry" (NSW Farmers, 2015, p. 11). The Egg Farmers of Australia (2015, p. 9) argued that, "the standard ignores the history and development of free range production systems in Australia". In other words, the standard attempted to define free range eggs in a way that was not consistent with existing industrial-scale free range egg production systems, and the supplier standards for free range eggs required by Australia's two dominant supermarkets.

The egg industry coalition focused on reframing two key aspects of the definition of free range: access to the range and stocking density. The coalition argued that the proposed definition of "access to the range" (The Treasury, 2015) was unworkable, because egg farmers could not be confident of meeting the definition in practice (Queensland United Egg Producers, 2015). Instead, the Egg Farmers of Australia (2015a, p.15) proposed its own definition of free range, which introduced the idea of "meaningful and regular access" to an outdoor range, in which hens are "free to roam and forage on an outdoor range" but should not actually need to roam in order to be considered "free range". Submissions from other stakeholders in the egg industry coalition expressed support for this definition of free range (e.g. Commercial Egg Producers Association of WA, 2015; NSW Farmers, 2015).

The egg industry coalition argued strongly for a maximum outdoor stocking density of 10,000 birds per hectare, reflecting the current production practices of many industrial-scale egg producers (e.g. Egg Farmers of Australia, 2015a; Victorian Farmers Federation, 2015). The ACCC had previously indicated that it did not believe that an outdoor stocking density of 10,000 hens per hectare was consistent with consumer expectations of eggs labeled free range (Fyfe and Millar, 2013). However, this maximum stocking density was consistent with the practices of Australia's two dominant retailers, Coles and Woolworths. Both had previously set a maximum stocking density for eggs labelled free range of 10,000 birds per hectare (Fyfe and Millar, 2013; Woolworths, 2013). Coles (2015, p.1) argued in its submission that it needed to offer customers a "high welfare, value egg" and that the best option was to have "all parties operating to at least a minimum higher welfare standard" (no public submission was available from Woolworths). There is no evidence that either Coles or Woolworths took an active part in the egg industry coalition and neither adopted a strong public position on the standard during the consultation.

Small-scale egg producers argued for a stocking density of 1,500-2,500 birds per hectare, consistent with their typical production practices (e.g. Katham Springs, 2015; Fleurieu Free Range Eggs, 2015). Small-scale egg producers were key stakeholders in a second "advocacy coalition", which included animal advocacy groups (e.g. Animals Australia, 2015; Voiceless, 2015), Australia's main consumer group Choice (2015) and Members of Parliament from the Australian Greens (e.g. Greens NSW, 2015; Rattenbury, 2015). This second coalition had advocated for several years for the development of a national information standard (see section 2.1), and now argued for a standard that reflected consumer expectations of free range eggs (e.g. 
Choice, 2015; RSPCA, 2015). This coalition defined the policy problem largely within the framework set out by the Consultation RIS, as a problem of consumer uncertainty about the meaning of free range eggs, and a need to codify the meaning of free range emerging from $\mathrm{ACCC}$ enforcement action in a national information standard.

\subsection{The decision RIS - a problem of industry uncertainty}

Six months after the consultation, consumer affairs ministers were presented with a 'Decision RIS' document that outlined four options for proceeding with the national information standard (see Table 3; The Treasury, 2016).

\begin{tabular}{|l|l|l|}
\hline Option 1 & Status Quo & $\begin{array}{l}\text { Continued enforcement of the Australian Consumer } \\
\text { Law's misleading and deceptive conduction provisions } \\
\text { together with ongoing education campaigns }\end{array}$ \\
\hline Option 2 & $\begin{array}{l}\text { Cap outdoor stocking density } \\
\text { and require disclosure of } \\
\text { maximum outdoor stocking } \\
\text { density on label }\end{array}$ & $\begin{array}{l}\text { An information standard that would require eggs labelled } \\
\text { free range to have a maximum outdoor stocking density } \\
\text { of 10,000 birds per hectare and to disclose their stocking } \\
\text { density }\end{array}$ \\
\hline Option 3 & $\begin{array}{l}\text { Definition of 'free range' and } \\
\text { disclosure labels }\end{array}$ & $\begin{array}{l}\text { An information standard that would meet the } \\
\text { requirements of Option 2, but would also provide a } \\
\text { definition of free range based on birds having } \\
\text { "meaningful and regular access" to an outdoor range }\end{array}$ \\
\hline Option 4 & $\begin{array}{l}\text { Definition of 'free range' and } \\
\text { 'open range' and disclosure } \\
\text { labels. }\end{array}$ & $\begin{array}{l}\text { An information standard that would meet all the } \\
\text { conditions of Option 3 but would also create an "open } \\
\text { range" category for eggs produced from hens at stocking } \\
\text { densities of 1,500 birds per hectare or lower. }\end{array}$ \\
\hline
\end{tabular}

Table 3: Options for the national information standard for free range egg labelling in the decision RIS

The options presented to ministers had now been reframed in terms of the egg industry coalition's definitions of free range. In particular, each of the options defined "free range" in terms of the stocking density of existing industrial-scale free range operations and of the major retailers, at 10,000 birds per hectare. The options presented also described access to the range in terms of the egg industry's proposed definition of "meaningful and regular access" rather than the "most birds, most days" definition of the Consultation RIS, which had drawn on ACCC enforcement cases in the Federal Court (The Treasury, 2015). The preferred option presented to ministers was Option 3: an information standard that would require eggs labelled free range to have a maximum outdoor stocking density of 10,000 birds per hectare and would define free range based on hens having "meaningful and regular access" to an outdoor range. The stocking density would also need to be disclosed on cartons. Consumer affairs ministers announced in March 2016 that they would proceed with this option (CAF, 2016).

This fundamental shift in the meaning of the policy problem and in the definition of free range eggs was quite explicit. The decision RIS document stated (The Treasury, 2016, p. 30): 
"A variety of stakeholders objected to a definition of 'free range' based upon the outcomes of recent ACCC enforcement cases for misleading labelling of eggs as 'free range'... This feedback, in combination with additional research on existing definitions of 'free range', is reflected in the revised options outlined in this decision regulation impact statement, as the case-law based definition is no longer proposed"

Moreover it was reinforced by a statement in the decision RIS that the national consumer regulator, the ACCC, had agreed to "adjust" its guidance in line with the new definition of free range eggs (The Treasury, 2016). The meaning of free range eggs had shifted from a definition based on consumer perceptions of free range to a definition based on the existing model of industrial-scale free range egg production, practised by the egg industry and the major retailers, regardless of whether Ministers chose to proceed with a national information standard for free range labelling. Weiss (1989) emphasises that policy definitions may be significant policy outcomes in their own right, and this was the case here. As Birkland (2011) emphasizes, the stakeholder group that is able to successfully define a policy problem will also be the group that shapes the solutions and prevails in the policy debate. The industrial-scale egg industry and the major retailers used their considerable power to redefine both.

\section{Discussion and Conclusions}

\subsection{Capturing the meaning of free range}

The outcome of the policy process to develop Australia's national information standard for free range egg labelling has the hallmarks of a straightforward case of "regulatory capture" (Dal Bo, 2006). However, our analysis reveals a more complex story. The development of a food labelling policy is a highly contested "regulatory space", and the outcomes of the policy process to develop a new standard will reflect the power relations between stakeholders within that space. The influence of the egg industry over the standard could be seen clearly in the shift in the problem definition that occurred during the development of the standard. Less immediately obvious, but no less significant, was the influence of Australia's two dominant retailers, who had already set standards for free range eggs, which underpinned the egg industry's proposed definition. The influence of the egg industry over the development of the standard was only possible with the tacit support of the retailers, the "power brokers" of the food system (Lang and Heasman, 2015). Moreover, the standards for "free range" set by Australia's retailers had, in turn, been influenced by consumer pressure and the activism of animal welfare groups (Parker et al 2017). Underlying this apparently simple case of "regulatory capture" is a complex network of stakeholder interactions and contestation.

The influence of the egg industry over the standard's development was also facilitated by the policy process itself, specifically by the emphasis of the Regulatory Impact Statements (RIS) process on economic analysis and minimizing the "cost burden" of new regulations for industry (DPMC, 2014). The preferred policy solution put to consumer affairs ministers in the Decision RIS was recommended as a good option partly because there would be little disruption for egg producers. They could "set and forget" production practices (The Treasury, 2016 p. 25), without needing to respond to consumer concerns about hen welfare. The influence of the egg industry was further bolstered through the "advocacy coalition" (Sabatier and Jenkins-Smith, 1999) formed during the RIS consultation, and particularly through the support of primary industries 
ministers within this coalition. Moreover, the appointment of a National Party Member of Parliament as Minister for Agriculture and Deputy Prime Minister in September 2013 created a further opportunity for the egg industry coalition to influence the standard. Shortly before Ministers announced the outcome of the national information standard policy process in March 2016, the Minister for Agriculture commented in the media that he and the Assistant Treasurer had "resolved the egg labelling issue between them" (Bettles, 2016). It was also announced that a new Agriculture Commissioner would be appointed to the ACCC, the ex-executive director of a national primary industry think tank and lobbying organization (Han, 2016).

\subsection{The potential for future change}

This policy outcome suggests that the primary industries still have considerable political power in Australia, and that the "cozy" relationship between government and primary industries continues (Marangos, 2009; Chen, 2016). Yet the development of the standard also represented a challenge to this industry power. A "policy window" was opened through civil society activism, although it led on this occasion to only incremental improvement, from the previous industry proposal of an outdoor stocking density of 20,000 birds per hectare (ACCC, 2012) to the marginally better 10,000 birds per hectare set in the new standard (The Treasury, 2016). Nonetheless, this consumer law challenge to the power of the egg industry suggests a vulnerability that may present opportunities to achieve further improvements in hen welfare through changes to the meaning of "free range".

Our analysis suggests that the potential to realise opportunities for change is likely to depend to a large extent on the policy position of the two dominant retailers on the future of free range egg production in Australia. However, Coles $(2015$, p.2) hinted in its submission to the RIS consultation that it recognizes the likelihood of further change, acknowledging that "the industry worldwide may be moving to the standard of 1500 birds per hectare", while emphasizing that considerable time would be needed for the industry to modify free range sheds and ranges. There are further signs of change in the industry, with one of Australia's three main egg producers setting a maximum stocking density of 1500 birds per hectare (Sunny Queen, 2016), and civil society advocacy for a stocking density of 1500 birds per hectare continues, particularly from the consumer group Choice (2016a). There is ongoing contestation about the meaning of "free range" in Australia, which may yet influence further regulation to improve free range production practices and hen welfare.

\subsection{Conclusions}

This paper illustrates how Australia's egg industry was able to "capture" a consumer law initiative to develop a national free range egg labelling standard, ensuring that "free range" was legally defined as industrial-scale free range in accordance with the existing practices of the industry and Australia's two dominant retailers. The consumer advocacy group Choice opened the first policy window by lodging a "super complaint" which led to the development of the new national information standard for free range egg labelling. But to work in practice, this new consumer standard needed to meet the requirements of Australia's two dominant retailers who defined "free range" in terms of industrial-scale production systems at an outdoor stocking density of 10,000 birds per hectare. The egg industry supported this position, and when a second policy window opened with the consultation on the Regulation Impact Statement, they formed a strong advocacy coalition. Their influence was further bolstered with the appointment of an influential Minister for Agriculture. Australia's retailers and the egg industry successfully 
"shifted the agenda" of the proposed consumer standard by redefining the policy problem, so that a standard initially put forward as a consumer law initiative to address consumer uncertainty became a standard that aimed to address a different problem, industry uncertainty. Ongoing stakeholder contestation over the meaning of "free range" may open new "policy windows" in future for regulation that increases the transparency of free range egg labelling in Australia and improves the welfare of layer hens, but much depends on the actions of Australia's two dominant retailers.

\section{Acknowledgements}

This work was supported by a Discovery Grant from the Australian Research Council (Grant number DP 150102168).

\section{References}

ACCC (2015) ACCC enforcement guidance - free range hen egg claims. October 2015. Canberra: Australian Competition and Consumer Commission.

ACCC (2013) ACCC institutes proceedings against free range egg producers. Media release 288/13, 10 December 2013.

ACCC (2012) Initial assessment of certification trademark application CTM1390450 filed by the Australian egg corporation limited. Canberra: Commonwealth of Australia.

ACCC (2008) Report of the ACCC Inquiry Into the Competitiveness of Retail Prices for Standard Groceries, Commonwealth of Australia.

Animals Australia (2015) Submission in relation to free range egg labelling consultation paper. 27 November 2015. Melbourne: Animals Australia.

Bettles, C. (2016) Keogh rejects 'ridiculous' ACCC claims. Farm Weekly. 3 March 2016, viewed 18 April 2016, http://www.farmweekly.com.au/news/agriculture/general/politics/keogh-rejectsridiculous-accc-claims/2751824.aspx?storypage $=0$.

Bettles, C. (2016a) RSPCA slam free range egg labelling standards, Farm Weekly, 3 April 2016, viewed 16 May 2017, http://www.farmweekly.com.au/news/agriculture/general/politics/rspcaslam-free-range-egg-labelling-standards/2752107.aspx

Birkland, T. (2011) Agenda setting, power and interest groups: An introduction to the policy process: Theories, concepts and models of public policy making. $3^{\text {rd }}$ edition. New York: M E Sharpe.

Blewett, N., Goddard, N., Pettigrew, S., Reynolds, C. and Yeatman, H. (2011) Labelling Logic Review of Food Labelling Law and Policy. Canberra: Department of Health and Ageing.

Brett, J. (2011) Fair Share: Country and City in Australia. Quarterly Essay 42. Black Inc. 
Burkard, E., Abbott, K., Black, J., Meidinger, E. and Wood, S. (2014) Transnational business governance interactions: Conceptualization and framework for analysis. Regulation \& Governance 8 (1):1-21.

Burke, B. (2015) Free Range Egg Labelling. Letter to the Australian Treasury, 26 November 2015.

CAF (2015) Joint Communique. Meeting of Ministers for Consumer Affairs. Legislative and Governance Forum on Consumer Affairs. Melbourne, Victoria. 12 June 2015.

CAF (2016) Joint Communique. Meeting of Ministers for Consumer Affairs. Legislative and Governance Forum on Consumer Affairs. Parliament House. Canberra. 31 March 2016.

Carey, R., Caraher, M., Lawrence, M. and Friel, S. (2016) Opportunities and Challenges in Developing a Whole-of-Government National Food and Nutrition Policy: lessons from Australia's National Food Plan. Public Health Nutrition 15, pp. 1-12.

Carpenter, D. and Moss, D. (2014) Introduction. In Carpenter, D. and Moss, D. (eds) Preventing regulatory capture: Special interest influence and how to limit it. New York: Cambridge University Press.

Chen, P. (2016) Animal welfare in Australia: Politics and policy. Sydney: Sydney University Press.

Choice (2016) Still on the shelf. Media release 31 March 2016. Canberra: Choice.

Choice (2016a) Ministers make free range eggs meaningless: Choice calls for boycott of bad eggs after new standard rubber stamps rip off. Media release 31 March 2016. Canberra: Choice.

Choice (2015) Free range eggs: the consumer perspective. Submission to Consumer Affairs Australia and New Zealand. November 2015. Canberra: Choice.

Choice (2013) Free range egg claims in NSW: Super-complaint to NSW Fair Trading. 29 August 2013. Sydney: Choice.

Choice (2012) Survey on Consumer Expectations of Free Range Egg Labelling. Key Findings Report May 2012.

Clapp, J. (2012) Food. Cambridge: Polity Press.

Clapp, J. \& Fuchs, D. (2009) Agrifood corporations, global governance and sustainability: a framework for analysis. In Clapp, J. and Fuchs, D. (eds) Corporate Power in Global Agrifood Governance, pp. 1 - 26. Cambridge, Massachusetts: MIT Press.

Clapp, J. \& Scrinis, G. (2017) Big Food, Nutritionism, and Corporate Power. Globalizations, 14 (4), pp. 578-595. 
Coles (2015) Submission to the free range egg labelling consultation paper. 27 November 2015. Melbourne: Coles.

Commercial Egg Producers Association of WA (2015) Consultation regulatory impact statement for free range egg labelling. Consumer Affairs Australia New Zealand. October 2015. Wanneroo: Commercial Egg Producers Association of Western Australia.

Commission of the European Communities (2009) Options for animal welfare and the establishment of a European Network of Reference Centres for the protection of welfare and animals. COM(2009) 584.

Commonwealth of Australia (2015) Agricultural competitiveness white paper. Canberra: Commonwealth of Australia.

Curtin, J. (2000) The voice and the vote of the bush: The representation of rural and regional Australia in the federal parliament. Canberra: Department of Parliamentary Services Parliamentary Library.

Dal Bo, E. (2006) Regulatory capture: A review. Oxford Review of Economic Policy 22 (2): 203 225.

Dixon, J. (2003) 'Authority, power and value in contemporary industrial food systems', International Journal of Sociology of Agriculture and Food 11 (1), pp. 31-39.

DPMC (2014) The Australian Government Guide to Regulation. Canberra: Department of the Prime Minister and Cabinet.

Egg Farmers of Australia (2015) New definition of free range. Media release 10 June 2015. Egg Farmers of Australia.

Egg Farmers of Australia (2015a) Submission to the Treasury Free Range Labelling Regulatory Impact Statement. November 2015. Egg Farmers of Australia.

EU Council (1999) EU Council Directive 1999/74/EC of 19 July 1999 Laying Down Minimal Standards for the Protection of Laying Hens [1999] OJ L 203/53.

FAWC (2006) Report on Welfare Labelling. London: Farm Animal Welfare Council.

Fleurieu Free Range Eggs (2015) Submission to the free range egg labelling consultation. South Australia: Fleurieu Free Range Eggs.

Fuchs, D. Kalfagianni, A. and Arentsen, M. (2009) Retail power, private standards and sustainability in the global food system. In Clapp, J. and Fuchs, D. (eds) Corporate Power in Global Agrifood Governance, pp. 93-124. Cambridge, Massachusetts: MIT Press. 
Fyfe, M. and Millar, R. (2013) 10,000 hens to a hectare is no free range: ACCC. The Age 5 March 2013.

Goodfellow, J. (2016) Regulatory capture and the welfare of farm animals in Australia. In Cao, D. and White, S. (eds) Animal law and welfare - international perspectives. New York:

Springer.

Gray, I. and Lawrence G. (2004) A future for regional Australia: Escaping global misfortune. Sydney: Cambridge University Press.

Greens NSW (2015) Greens NSW response to the regulation impact statement: Free range egg labelling. Sydney: Greens NSW.

Guest, G., McQueen, K and Namey, E. (2012) Applied thematic analysis. Sage.

Guthmann, J. (2007) The Polanyian Way? Voluntary Food Labels as Neoliberal Governance. Antipode, pp. 456-478.

Han, E. (2016) New appointee will scramble ACCC's free range egg work, animal activists claim. Sydney Morning Herald 2 March 2016, viewed 29 March 2016, http://www.smh.com.au/business/retail/new-appointee-will-scramble-acccs-free-range-eggwork-animal-activists-claim-20160301-gn7ixd.html.

Hancher, L. and Moran, M. (1998) Organizing regulatory space. In Baldwin, R., Scott, C. and Hood, C. (eds) A reader on regulation. Oxford Readings in Socio-legal Studies. Oxford: Oxford University Press.

Industry Commission (1991) Statutory Marketing Arrangements for Primary Products. Report No. 10, Australian Government Publishing Service.

Jaffee, D. \& Howard, P. (2010) Corporate cooptation of organic and fair trade standards. Agriculture and Human Values, 27(4), pp. 387-399.

Jelsoe, E. (2015) Dietary guidelines: nutritional health communication versus sustainable food policy. The Journal of Transdisciplinary Environmental Studies 14 (2), pp. 35-50.

Katham Springs (2015) Submission to the free range egg labelling consultation. South Australia: Katham Springs.

Kingdon, J. W. (2011) Agendas, Alternatives and Public Policies. New York: Longman, pp. 165195.

Klintman, M. and Bostrom, M. (2004) Framings of Science and Ideology: Organic Food Labelling in the US and Sweden. Environmental Politics 13 (3), pp. 612-624. 
Kwak, J. (2014) Cultural capture and the financial crisis. In Carpenter, D. and Moss, D. (eds) Preventing regulatory capture: Special interest influence and how to limit it. Cambridge: Cambridge University Press.

Lang, T. and Heasman, M. (2015) Food wars: The global battle for mouths, minds and markets. Second edition. Abingdon: Routledge.

Lewis, T, and Huber, A. (2015) "A Revolution in an Eggcup? Supermarket Wars, Celebrity Chefs and Ethical Consumption." Food, Culture \& Society 18 (2): 289-307.

Marangos, J. (2009) An Institutional and Economic Complexity Approach to the Development of Agricultural Groups in Australia. Journal of Economic Issues 43 (1), pp. 43-68.

Mench, J., Sumner, D. and Rosen-Molina, J. (2011) Sustainability of egg production in the United States - The policy and market context. Poultry Science 90, pp. 229-240.

Mialon, M., Swinburn, B., Allender, S. \& Sacks, G. (2016) Systematic examination of publicly-available information reveals the diverse and extensive corporate political activity of the food industry in Australia. BMC Public Health, 16(1), pp. 2-13.

Miele, M. (2011) The Taste of Happiness: Free-Range Chicken. Environment and Planning A 43, pp. 2076-2090.

NAWC (2012) Animal Welfare (Layer Hens) Code of Welfare 2012, 6 December 2012. Canberra: National Animal Welfare Advisory Committee.

Nestle, M. (2013) Food politics: How the food industry influences nutrition and health. Berkley: University of California Press.

NSW Fair Trading (2013) NSW Fair Trading response to Choice super complaint on free range egg claims in NSW. 7 December 2013. Sydney: NSW Fair Trading.

NSW Department of Primary Industries (2015) Submission to the Commonwealth Government egg labelling consultation. December 2015. Sydney: NSW Department of Primary Industries.

NSW Farmers (2015) Regulation impact statement. Free range egg labelling. St Leonards: NSW Farmers Association.

Parker, C. (2014) The food label as governance space: free range eggs and the fallacy of consumer choice. Recht der Werkelijkheid 35 (3), pp. 101-133.

Parker, C. and De Costa, J. (2016) Misleading the ethical consumer: the regulation of free-range egg labelling. Melbourne University Law Review 39 (3), pp. 895-949.

Parker C. and Scrinis, G. (2014). Out of the cage and into the barn: supermarket power food system governance and the regulation of free-range eggs'. Griffith Law Review 23 (2), pp. 318347. 
Parker, C., Carey, R., De Costa, J. and Scrinis, G., The hidden hand of the market: who regulates animal welfare under a labelling for consumer choice approach? Accepted by Regulation and Governance 4 November 2016. Forthcoming 2017.

Productivity Commission (2016) Chapter 5: Regulation of farm animal welfare" in Regulation of Australian Agriculture, Report No. 79, Commonwealth of Australia, Canberra, 15 November 2016, pp 199-259 Available at http://www.pc.gov.au/inquiries/completed/agriculture/report/agriculture.pdf

Queensland United Egg Producers (2015) Response to the consultation regulation impact statement. Labelling of eggs - free range. Brisbane: Queensland United Egg Producers.

Rattenbury, S. (2015) Submission to consultation on free range egg labelling. Canberra: Office of Shane Rattenbury MLA.

Richards, Z., Thomas, S. L., Randle, M. \& Pettigrew, S. (2015) Corporate Social Responsibility programs of Big Food in Australia: a content analysis of industry documents. Australian and New Zealand Journal of Public Health. Online; doi: 10.1111/1753-6405.12429

Ridgway, E., Lawrence, M. and Woods, J. (2015) Integrating environmental considerations into food and nutrition policies: insights from Australia's national food plan. Frontiers in Nutrition 2. September 2015.

Roff, R. (2007) Shopping for Change? Neoliberalizing Activism and the Limits to Eating NonGMO. Agriculture and Human Values 24, pp. 511-522.

RSPCA (2015) RSPCA Australia submission to free range egg labelling consultation paper. Canberra: RSPCA Australia.

Sabatier, P. and Jenkins-Smith, H. (1999) The Advocacy Coalition Framework: An assessment. In Sabatier, P. (ed) Theories of the policy process, pp. 117-166. Boulder: Westview Press.

Sampson, A (2015) National Standard to eliminate uncertainty in free range labelling. The Weekly Times 12 June 2015.

SCARM (2000) Synopsis Report on the Review of Hen Housing and Labelling of Eggs in Australia. Standing Committee on Agriculture and Resource Management. Canberra: Commonwealth of Australia.

Scott, C. (2001) Analysing regulatory space: fragmented resources and institutional design. Public Law (Summer), pp. 329-53

Smith, A. (2011) Poultry hormone claims mislead, say consumer groups. The Sydney Morning Herald, 8 October 2015. 
Smyth, E. (2009) In whose interests? Transparency and accountability in the global governance of food: Agribusiness, the Codex Alimentarius and the World Trade Organization. In Clapp, J. and Fuchs, D. (eds) Corporate Power in Global Agrifood Governance, pp. 93-124. Cambridge, Massachusetts: MIT Press.

South Australian Local Egg Industry Section (2015) Submission in response to regulatory impact discussion paper (October 2015) National free range egg labelling. 22 November 2015. South Australia: South Australian Local Egg Industry Section.

Stigler, G (1971) The theory of economic regulation. Bell Journal of Economics and Management Science 2, pp. 3 - 21.

Stucker, D and Nestle, M (2012) Big food, food systems and global health. PLoS Med 9 (6): e1001242.

Sunny Queen (2016) Free range eggs, viewed 5 October 2016, http://www.sunnyqueen.com.au/products/free-range-eggs/.

The Treasury (2015) Free range egg labelling: Consultation paper. October 2015. Canberra: Australian Government, The Treasury.

The Treasury (2016) Free range egg labelling: Decision regulation impact statement. March 2016. Canberra: Australian Government, The Treasury.

Tonkin, B. (2014) IBIS World Industry Report A0172: Egg Farming in Australia. IBIS World.

Victorian Farmers Federation (2015) Submission to the Treasury. Free range egg labelling regulatory impact statement. Melbourne: Victorian Farmers Federation.

Voiceless (2015) Free Range Egg Labelling Consultation Paper. Submission to the Australian Treasury, 27 November 2015. Sydney: Voiceless.

Weiss, J. (1989) The Powers of Problem Definition: The Case of Government Paperwork. Policy Sciences 22, pp. 97-121.

Williams, J. (2015) Submission to Free Range Eggs Consultation Paper. Senator John Williams: The Nationals Senator for NSW. Inverell: NSW Nationals.

Woolworths (2013) Corporate Responsibility Report 2013. Sydney: Woolworths. 